\title{
Aniversario del martirio de los jesuitas
}

Han pasado nueve años desde el día en que nuestros hermanos jesuitas, junto con sus dos empleadas, murieron asesinados. Permítanme compartir algunos pensamientos que esta fecha trae a mi corazón.

Hoy hemos comenzado a leer, en la liturgia, el libro del Apocalipsis, que fue escrito, como sabemos, para confortar a los cristianos que atravesaban un momento de terrible persecución. En este libro santo encontramos unas palabras que vienen espontáneamente a mi memoria al evocar hoy a los Padres y a las dos mujeres que murieron esa madrugada: "Uno de los ancianos tomó la palabra y me dijo: 'Esos que están vestidos con vestiduras blancas, ¿quiénes son y de dónde han venido?'. Yo le respondí: 'Señor mío, tú lo sabrás'. Me respondió: 'Esos son los que vienen de la gran tribulación; han lavado sus vestiduras y las han blanqueado con la sangre del cordero'" $(7,14 s)$.

Nos volvemos a hacer la pregunta, a nueve años de distancia, y se agolpan los recuerdos. Cada uno tiene su propia experiencia de cómo vivió el momento dramático en que escuchó la increíble noticia. Yo la recibí mientras desayunaba con Monseñor Rivera en la residencia arzobispal. La lista con los nombres de los muertos se iba desgranando en la voz entrecortada del mensajero. Luego nos levantamos y nos pusimos la sotana para venir al lugar de la masacre. Sólo traíamos una estola y el ritual. Una foto que recoge el instante del encuentro con la escena patética dio la vuelta al mundo: donde ahora florecen unos rosales yacían entonces los cuerpos destrozados de los Padres.

1. Homilía celebrada por Monseñor Gregorio Rosa Chávez, Obispo Auxiliar de San Salvador, en el Noveno Aniversario de los Mártires de la UCA. 
El Padre Tojeira nos explicó brevemente lo sucedido. Luego llamé por teléfono al presidente Cristiani para pedir que nos recibiera urgentemente. En la reunión, Monseñor Rivera presentó formalmente la protesta de la Iglesia por lo sucedido. Protestó también por la cadena radial que destilaba tanto veneno contra todo aquél o aquélla que eran considerados opositores al régimen. En la lista estaban los hermanos que ahora recordamos. El diálogo fue tenso. Pasamos luego por la nunciatura, donde encontramos comprensión y profunda sintonía de sentimientos. Al volver a la casa, tratamos de comer algo. Luego, mientras descansábamos un poco, escuchamos exactamente estas palabras, vomitadas por un altoparlante: "Ellacuría y MartínBaró ya cayeron; sigamos matando comunistas".

Eso fue lo que sucedió aquí. En el cielo la escena del Apocalipsis volvió a revivir. Y a la pregunta de quiénes son y de dónde vienen esos ocho cuerpos masacrados, la respuesta tuvo que ser la misma: "Estos son los que vienen de la gran tribulación". Era la tribulación de la guerra, con todo su cortejo de violencia ciega y abominable. Era la tribulación de todo un pueblo cuyos derechos eran conculcados masivamente.

Estas son algunas de las víctimas de una cadena radial que envenenó las mentes de quienes después empuñaron los fusiles, como dijo en esa ocasión Monseñor Rivera. Por una especial delicadeza de la providencia, también Monseñor Rivera, cuya actitud valiente y firme recuerda con gratitud la Compañía de Jesús, partió en este mismo mes de noviembre, cinco años más tarde.

En esta Eucaristía recordamos a los mártires y nos comprometemos de nuevo con sus ideales. Sentimos que la gran tribulación aún no ha pasado, porque El Salvador firmó la paz pero no tiene la vivencia cotidiana de la paz. A las tribulaciones de las estructuras injustas que siguen aplastando a las mayorías empobrecidas se une la causada por los embates de la naturaleza.

Que nuestra presencia aquí sea no sólo para hacer memoria, sino también para continuar la profecía. El Apocalipsis habla de un cielo nuevo y una tierra nueva en la que brille la justicia. Esa tarea no ha terminado.

San Salvador, 16 de noviembre de 1998. 